\title{
ENVIRONMENTAL MONITORING OF DREDGING AT THE PORT OF ANGRA DOS REIS
}

\author{
A.L.S. MURTA ${ }^{1}$, G.E.C. KVASSAY ${ }^{2}$, G.S. DINIZ ${ }^{3}$, M.A.V. FREITAS ${ }^{4}$, M. P. A. MURTA ${ }^{5}$ \\ Universidade Federal Fluminense, Universidade Federal do Rio de Janeiro, Universidade Veiga de Almeida \\ aureliomurta@id.uff.br ${ }^{1}$
}

Artigo submetido em 14/09/2018 e aceito em 23/04/2019

DOI: $10.15628 /$ holos.2019.7725

\section{ABSTRACT}

Dredging activities in port areas are intended to expand the ports' activities and maintain adequate depth in the access channels, berthing areas and basins of evolution. The environmental license granted for maintenance dredging in the port of Angra dos Reis demanded the continuous monitoring of water and sediment variables in the area directly influenced. Dredging is known to impact the environment, and an intensive monitoring program is an important tool for environmental protection. This study monitored water and sediments in the dredging and disposal area before, during and after dredging operations. The water was analysed by measurement of dissolved oxygen, turbidity,
\end{abstract}

temperature, salinity, $\mathrm{pH}$, transparency and TSS. To study the sediment in the disposal area, surface samples were collected for analysis of the parameters listed in CONAMA Resolution 344/2004. The results revealed that there was no influence of dredging on the water in the disposal area. However, in the dredging area, an increase in turbidity, TSS and phosphorus was observed during the dredging. In the evaluation of the sediments, increases in the concentration of sandy sediments and in the concentrations of some metals were observed. However, no compound increased in concentration to a level above that specified in CONAMA 344/2004.

KEYWORDS: Environmental monitoring; Dredging; Heavy metals; Nutrients.

\section{MONITORAMENTO AMBIENTAL DE ATIVIDADES DE DRAGAGEM NO PORTO DE ANGRA DOS REIS}

\section{RESUMO}

Atividades de dragagem em portos tem como função expandir as atividades realizadas nestes locais com fins da manutenção de profundidade adequada nos canais de acesso, zonas de manobra e atracação e espaços em bacias hidrográficas. As licenças ambientais fornecidas para a manutenção de dragagem no porto de Angra dos Reis demandam monitoramento contínuo da água e controle de variáveis relacionadas a sedimentos na área. Sabe-se que a dragagem afeta o meio ambiente. Diante disso, um programa de monitoramento é uma importante ferramenta para a proteção ambiente. Este estudo visou relatar como ocorreu o monitoramento das águas e os sedimentos, na área de dragagem e descarte antes, durante e após as operações de dragagem. A água foi analisada por meio da medição de oxigênio dissolvido, da sua turbidez, temperatura, salinidade, $\mathrm{pH}$ e transparência e total de sólidos suspensos. Para estudar o sedimento na área de descarte, amostras da superfície foram colhidas visando a análise dos parâmetros listados na Resolução número 344/2004 do Conselho Nacional do Meio Ambiente-CONAMA. Os resultados revelam que não havia influência de dragagem na água na área de descarte. Entretanto, foram identificados aumento de turbidez, transparência e total de sólidos suspensos e presença de fósforo durante a dragagem. $\mathrm{Na}$ avaliação dos sedimentos, foi possível identificar aumento na concentração de sedimentos arenosos e de alguns metais. No entanto, nenhum composto aumentou sua concentração para um nível acima do especificado no CONAMA 344/2004.

PALAVRAS-CHAVE: Monitoramento Ambiental ; Dragagem; Metais Pesados; Nutrientes. 


\section{INTRODUCTION}

Dredging is essential for the opening and maintenance of maritime and freshwater navigation channels. It plays an important role in the clean-up of bodies of water that contain contaminated sediments and in the recuperation of the drainage capacity of watercourses (Góes, 2002). Dredging involves the removal of sediment and rocks from the bottom of rivers, lagoons, channels and other water bodies to deepen and widen these navigation fairways (Torres et al., 2009). The principal aim of dredging in port regions is the maintenance of adequate depth in the access channels, mooring areas and evolution basins.

Historically, most ports were founded in estuaries and developed, over time, into centres of population and industry. Navigation channels within estuaries and at port entrances require frequent dredging to remain open (Gibertoni, 1998; Torres et al., 2009). Dredging is therefore necessary at most ports, including the Port of Angra dos Reis, located in the estuary of Ilha Grande Bay, which is subject to intense natural processes of sedimentation. The access channel, evolution basin and mooring berth were dredged from April to October 2010 to recover their original operational depths (INPH, 2009).

Dredging usually involves the removal of large volumes of sediments and their disposal at specific sites, e.g., open-water disposal or confined disposal (Torres et al., 2009). A total of $90,000 \mathrm{~m}^{3}$ of sediment was dredged from the Port of Angra dos Reis, and this volume was dumped into the ocean disposal area determined by the governing environmental agency, the State Environmental Institute (Instituto Estadual do Ambiente - INEA), at a distance of 32 nautical miles to the south of the entrance to Ilha Grande Bay and at a depth greater than 50 m.

Although dredging makes a significant contribution to economic growth, dredging activities may generate adverse environmental impacts, either as a direct result of the dredging itself or as a result of the disposal of the dredged matter. The most commonly reported impacts of dredging are morphological alterations in the water bodies, damage to the benthonic community, increased turbidity in the water mass and contamination of the water table by inadequate disposal of dredged matter (Góes, 2002). According to Torres (2000), the retention of toxic products in sediments is highly significant in terms of ecological impacts. The USACE (1998) has stated that estuaries and bays usually receive industrial, domestic and port wastes from multiple sources; the sediments in these water bodies are therefore frequently contaminated with metals and persistent organic compounds, which generally exhibit high bio-accumulative and toxic potentials. Sediments accumulate pollution; consequently, the re-suspension of sediments from the seabed re-mobilises both contaminants and nutrients, which affects water quality and the global chemistry of the environment. Because of such contamination in dredging operations, the disposal of dredged material must be planned and conducted carefully to reduce possible risks and avoid or minimise the remobilisation of contaminants and their toxic effects on the biota (Torres et al., 
2009). Environmental studies on dredging activities should include permanent and continuous environmental monitoring and identify water and sediment quality.

Environmental impact studies are generally required as pre-requisites to environmental licensing and normally take the form of environmental programs aimed at evaluating and monitoring potential impacts on the composition and structure of the physical, chemical and biotic fields (Kennish, 1994; Góes, 2002). The Virtual Institute of Global Change (IVIG/COPPE/UFRJ) at the Federal University of Rio de Janeiro, in conjunction with the Docks Company of Rio de Janeiro (CDRJ), implemented an environmental program to monitor the dredging on the access channel, evolution basin and mooring berth of the Port of Angra dos Reis, with a view toward the identification and evaluation of the degree of environmental interference that resulted from the dredging work.

In the present study, physicochemical analyses of the water and surface sediments were performed before, during and after the dredging operation, in accordance with specific conditions imposed on the environmental permit issued by the State Environmental Institute (INEA). Analyses performed prior to the dredging enabled characterisation of the area of influence of the work and served as a basis of comparison for evaluation of the environmental impact of the dredging. Two distinct regions were monitored within the area of influence: the dredging area and the area of ocean disposal of the dredged matter.

Before the dredging, as part of the licensing process of this activity, the Docks Company of Rio de Janeiro (CDRJ, 2008) examined the sediment to be dredged from the Port of Angra dos Reis, as specified in CONAMA Resolution 344/2004 (issued by the Brazilian National Environmental Council - CONAMA) (Brasil, 2004). This resolution sets out the general guidelines and procedures for the evaluation and classification of matter that is to be dredged in Brazilian waters. It defines quality criteria on the basis of two levels of classification of matter: Level 1 indicates a threshold below which there is a low probability of adverse effects on the biota, whereas Level 2 sets out the threshold above which there are probable adverse effects on the biota.

According to CDRJ (2008), the particle size characteristics of the dredged sediments in samples from both the surface and subsurface indicate that the material is predominantly silty-clay. With respect to chemical characteristics, in general, the sediments contained concentrations below level 1 of CONAMA 344/2004: TOC (8.86\%), total nitrogen (726.25 $\mathrm{mg} / \mathrm{kg})$, total phosphorus $(616.25 \mathrm{mg} / \mathrm{kg})$, some metals such as cadmium $(0.51 \mathrm{mg} / \mathrm{kg})$, chromium $(34.9 \mathrm{mg} / \mathrm{kg})$ and zinc $(77.6 \mathrm{mg} / \mathrm{kg})$, PAHs, organochlorine pesticides and PCBs. Most of these last three classes of compounds were detected at levels of "nd" (undetectable). However, the dredged sediments contained concentrations of copper $(57.7 \mathrm{mg} / \mathrm{kg})$, mercury $(0.58 \mathrm{mg} / \mathrm{kg})$, nickel $(23.7 \mathrm{mg} / \mathrm{kg})$, lead $(61.2 \mathrm{mg} / \mathrm{kg})$ and arsenic $(9.0 \mathrm{mg} / \mathrm{kg})$ between levels 1 and 2 of CONAMA 344/2004. 


\section{MATERIAL AND METHODS}

\subsection{Study area}

The Port of Angra dos Reis is located in the municipality of the same name in Ilha Grande Bay on the southern coast of the state of Rio de Janeiro, Brazil. The bay is located between the $44^{\circ} \mathrm{W}$ and $44^{\circ} 40^{\prime} \mathrm{W}$ meridians and between the $23^{\circ} \mathrm{S}$ and $23^{\circ} 42^{\prime} \mathrm{S}$ parallels. Ilha Grande Bay forms an estuary system together with Sepetiba Bay.

The coastal zone where the dredging was performed is located in an area in which both the terrestrial and marine ecosystems are relatively well-preserved. The relief is wellpronounced and composed of a rugged coastline of steep slopes, cliffs and bays on the southern Serra do Mar region as well as several islands. The coastal areas have been subject to relatively little development. The bay beaches (low energy) are enclosed in recesses in the relief.

The sub-marine area is located in the central channel between the Bay of Ilha Grande and Sepetiba Bay. These bays present distinct hydrographic characteristics and hydrodynamic behaviours. Ikeda \& Stevenson (1982) have observed that the water flow regime is unidirectional from the west of Ilha Grande to the east. The same authors have also indicated that the current in the channel is modulated, i.e., it suffers reduction in intensity during low tides but not to such an extent as to change its direction.

The water of the dredging area was analysed at two sampling sites: A1 (Lat 23 $00^{\prime} 38.2^{\prime \prime}$ S; Long $44^{\circ} 18^{\prime} 56.4^{\prime \prime} \mathrm{W}$ ) and $\mathrm{A} 2$ (Lat $23^{\circ} 00^{\prime} 55.5^{\prime \prime} \mathrm{S}$; Long $44^{\circ} 18^{\prime} 46.5^{\prime \prime} \mathrm{W}$ ). The distance between the different sites was approximately $600 \mathrm{~m}$.

Water and sediment in the disposal area was analysed at two sampling stations: the southwestern disposal area, BF-A1 (Lat $23^{\circ} 28^{\prime} 38.2^{\prime \prime}$ S; Long $44^{\circ} 18^{\prime} 56.4^{\prime \prime} \mathrm{W}$ ), and the

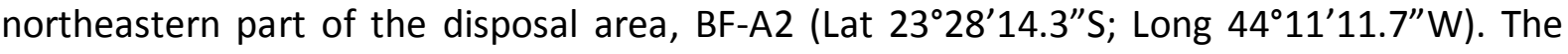
distance between the different stations was approximately $1 \mathrm{~km}$.

Figure 1 sets out the localisation of the Port of Angra dos Reis and highlights the dredging area and the monitoring sites, as well as the sites of the disposal area. 


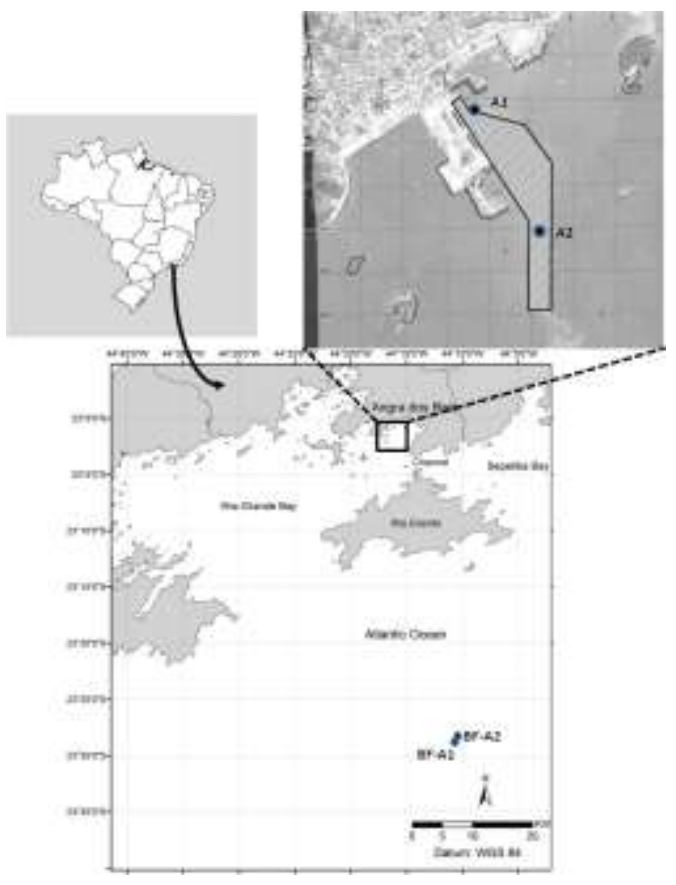

Figure 1: Map showing the location of the area studied and the points of sampling in the dredging area and the area of ocean disposal. Source: IVIG (2015)

\subsection{Water: Dredging and disposal area}

Water variables were measured via in situ readings of the following parameters: salinity (conductivity, salinity Orion 142), temperature (OXI 197 WTW), pH (pH meter 197 WTW), dissolved oxygen (OXI 197 WTW), turbidity (Hach 2100) and transparency (Secchi Disc). Furthermore, samples of water were gathered with a Van Dorn-type oceanographic bottle for analysis and quantification of the total suspended solids (TSS), total phosphorus and nitrogen $\left(\mathrm{NH}_{3}\right.$ and $\left.\mathrm{NH}_{4}\right)$.

The analyses of ammonia, ammoniac nitrogen, TSS and phosphorous were performed according to the methodology established in APHA (2005). The analyses of ammoniac nitrogen and ammonia were performed according to methodologies $4500 \mathrm{~B}$ and $\mathrm{C}$ using distillation followed by colourimetry. For the analysis of the concentration of phosphorous, sample particles are digested with potassium persulphate and sulphuric acid. The determination was made by spectrophotometric readings in accordance with method 4500 . To determine the concentration of TSS, the sample was filtered through a glass-fibre filter and dried at approximately $105^{\circ} \mathrm{C}$ for $1 \mathrm{~h}$ or until all humidity was removed, in accordance with method 2540D. The concentration of suspended solids was determined from the difference in mass of the filter paper (filter paper after filtration - filter paper before filtration) and the volume of the filtered sample.

A total of five samplings were performed in the dredging area: one prior to the dredging (March 2010), three while dredging was underway (July and August 2010) and one after the dredging was complete (December 2010). Samples were collected from the A1 and A2 points at two depths: at the surface (depth of $20 \mathrm{~cm}$ ) and at the near-bottom (1 $\mathrm{m}$ above the layer of sediments). 
Sampling was performed in the disposal area prior to the commencement of dredging activities (March 2010) and again after the end of dredging (December 2010). Samples were collected from the BF-A1 and BF-A2 sites at three depth levels: at the surface (depth of 20 $\mathrm{cm}$ ), in the middle of the water column and from the seabed ( $1 \mathrm{~m}$ above the layer of sediment).

\subsection{Sedimental: Disposal area}

Surface samples of sediments were gathered from the region to evaluate the possible impact of dredging on the sediment in the ocean disposal area. Samples were gathered before (March 2010) and after the dredging activities (December 2010) at both sites (BF-A1 and BFA2).

A stainless steel non-zinc Petersen grab sampler (model HydroBios) with a grab capacity of $60 \mathrm{~cm}^{3}$ of sediment (corresponding to a layer $20 \mathrm{~cm}$ from the seabed) was used to gather sediment samples. Sampling was performed in accordance with IMO (2005) guidelines, and the samples were stored and conserved in accordance with APHA (2005).

The samples were sent to the laboratory for granulometric analysis and chemical quantification of the transition metals ( $\mathrm{Cd}, \mathrm{Cu}, \mathrm{Cr}, \mathrm{Hg}, \mathrm{Ni}, \mathrm{Pb}$ and $\mathrm{Zn}$ ) and semi-metals (arsenic), organochlorine pesticides, total polychlorinated biphenyls (PCBs), polycyclic aromatic hydrocarbons (PAHs), total organic carbon (TOC) and nutrients (P-total and N-kjeldahl) in the sediments, as required by CONAMA Resolution 344/2004 (Brasil, 2004).

The granulometric analyses were performed in accordance with the technique recommended by the Brazilian Agency of Technical Norms (ABNT, 1995). The classification complied with the Wentworth (1922) granulometric scale. For the granulometric analyses, the samples were first dried and then sifted through various sizes of pores. The mass retained at each sifting was weighed, and the percentage of each fraction was calculated in relation to the total sifted sample mass.

The analyses of TOC were performed in accordance with the 5310B methodology established by APHA (2005) via de-carbonation using sulphuric acid and high-temperature oxidation $\left(260 \pm 10^{\circ} \mathrm{C}\right)$ with sodium persulphate. The carbon dioxide released from the organic matter was absorbed in an alkaline solution, which was then titrated with hydrochloric acid.

The N-Kjeldahl content was analysed via digestion of the samples with sulphuric acid and sodium persulphate and determined by colourimetry, in accordance with the 4500A and 4500B methodologies described by APHA (2005). The analysis of phosphorous was also performed according to the 4500 method described by APHA (2005).

Ultrasonic extraction was used to analyse semi-volatile organic composts (PAHs, PCBs and pesticides) following methodology $3050 C$ described by the USEPA (2007a). The quantification was performed via gas chromatography and mass spectrometry, as prescribed under method 8270D established by the USEPA (1998).

The metals ( $\mathrm{Cd}, \mathrm{Cu}, \mathrm{Cr}, \mathrm{Ni}, \mathrm{Pb}, \mathrm{Hg}$ and $\mathrm{Zn}$ ) and semi-metal (As) were extracted from sediments according to USEPA method 3050B (USEPA, 1996) through acid digestion with 
concentrated nitric acid and hydrogen peroxide (30\%) on a plate heated to approximately $95^{\circ} \mathrm{C}$. Quantification, except for that of mercury, was performed via inductively coupled plasma-atomic emission spectrometry (ICP-AES), in accordance with method 6010C, as per USEPA (2007b). The quantification of mercury followed the 3112B methodology described in APHA (2005) via inductively coupled plasma-mass spectrometry (ICP-MS).

\section{RESULTS}

\subsection{Water}

The results of water monitoring are presented in Table 1. The data were compared with the maximum concentration limits recommended for class 2 saline water by the CONAMA 357/2005 (Brasil, 2005) federal legislation applicable to the estuary (dredging area) and the ocean area (disposal area).

\subsection{Dredging area}

During the monitoring, the transparency readings ranged from $1.25 \mathrm{~m}$ (August 7) to $3.4 \mathrm{~m}$ (August 21); both readings were recorded during the dredging. The readings for average transparency before and after the dredging were similar. During the monitoring in the dredging area, the temperature varied between $21.3^{\circ} \mathrm{C}$ (August/near bottom) and $29.8^{\circ} \mathrm{C}$ (March/surface). The lowest temperatures were always registered at the deepest layers and during the months when dredging activities were underway (July and August).

The recorded $\mathrm{pH}$ readings were similar at all stages of the dredging, with values that ranged from 7.59 (December/seabed) to 7.9. No pH variation was observed between depth levels or between the different stages of the dredging process. A similar pattern was observed with respect to the salinity of the dredging area. The recorded salinity readings ranged from 29.6 (March/surface) to 33.6 (December/near-bottom).

The concentration of dissolved oxygen (D.O.) was consistently low for all monitored sites during all stages of the dredging. The average readings ranged from 3.57 (March/nearbottom) to 7.28 (surface/August). With the exception of a sample taken on August 7 at the deepest layer, the greatest concentrations of D.O. were recorded at the surface. Only the near-bottom samples gathered before and after the dredging contained D.O. levels below the lower threshold set out in CONAMA 357 with an established limit $>5 \mathrm{mg} / \mathrm{L}$.

Considerable variation was observed in the turbidity and in the TSS levels of the water during monitoring, as shown in Figure 2. The turbidity varied from 0.8 (August/surface) to 32.8 (July/near-bottom). The greatest levels of turbidity were recorded at near-bottom during all stages of the work. The values observed from TSS varied from 0.5 (December 2010) to 157 (July 2010), and the greatest concentrations of solids were recorded at the near-bottom layers. Again, the sole exception was on August 7, when the readings taken at the surface and at near-bottom were the same. The highest readings for TSS were recorded during the dredging, and the readings taken in the post-dredging period were much lower than those taken during the other monitored periods. 
The readings recorded for the chemical parameters of ammoniac nitrogen, ammonia and total phosphorus indicated concentrations during the 3 phases of dredging activity that were considerably homogenous, below the detectable limits of the analytical methodologies and below the recommended CONAMA 357/2005 Resolution thresholds. The sole exception was the concentration of phosphorous registered at the near-bottom during dredging activity (July 3, 2010), which showed a value close to the CONAMA Resolution threshold.

\subsection{Disposal area}

The water column transparency before and after the dredging activity was similar. The temperatures showed similar patterns before and after, with the highest temperatures being recorded at the surface and the temperatures decreasing towards the seabed. In general, the temperature ranged from 20.7 (March/near-bottom) to $27.3^{\circ} \mathrm{C}$ (March/surface).

The $\mathrm{pH}$ and salinity readings exhibited no significant variations between depth levels or between the two periods analysed. The $\mathrm{pH}$ readings varied from 7.82 (March/surface) to 8.09 (December/near-bottom). The registered salinity varied from 33.8 (March/surface) to 35.1 (December/near-bottom).

Perceive in table 1, the D.O. concentrations varied little throughout the period of monitoring and between the different depths analysed. The D.O content varied from 4.96 (March/surface) to 6.48 (December/surface). The D.O readings were close to the limit established in CONAMA Resolution 357/2005.

During the period analysed, the turbidity of the water column ranged from 0.23 March/surface) to 1.46 (March/near-bottom). With the exception of the surface, the greatest turbidity was observed in the water column prior to dredging. According to the turbidity measurements, the greatest concentrations of TSS were observed at all monitored depths prior to the commencement of dumping of the dredged sediment. The TSS values varied widely between the two samplings: 2.5 (December/mid-water) to 38.9 (March/near-bottom).

The concentrations recorded for chemical parameters (ammoniac nitrogen, ammonia and total phosphorous) were lower than the CONAMA 357/2005 Resolution recommended limits for both monitored periods.

\subsection{Sediments}

The granulometric composition of the surface sediments in the disposal area prior to the displacement of the sediment dredged at the Port of Angra dos Reis was $54.5 \%$ sand, $30.8 \%$ silt and $14 \%$ clay. Following the removal of the dredged sediments, the observed granulometric composition was $75.8 \%$ sand, $15.2 \%$ silt and $9 \%$ clay (Fig. 2). After dredging increase in the sand percentage and a decrease in the percentage of silt and clay were observed in the disposal area. 
Although both of the monitored sites presented sandy-silt characteristics at both sampling times, textural heterogeneity was observed in the disposal area. The sample from BF-A1 site contained higher percentages of clay (22.5\%) than did the BF-A2 site (6.8\%) prior to the dislocation of the dredged material, whereas the BF-A2 sample contained higher concentrations of sand (66.7\%) than did BF-A1 (42.4\%). At the end of the dredging, this position was inverted, with higher concentrations of clay observed at BF-A2 (18\%) and no clay sediment observed at BF-A1. 
MURTA ET AL (2019)

HOLDS

Table 1: Physico-chemical composition of water at the dredging zone and the disposal zone before, during and after dredging.

\begin{tabular}{|c|c|c|c|c|c|c|c|c|c|}
\hline \multirow{3}{*}{ Depth } & \multirow{3}{*}{ Parameters } & \multirow{3}{*}{$\begin{array}{c}\text { CONAM } \\
\text { A } 357 / 05\end{array}$} & \multicolumn{5}{|c|}{ Dredging area } & \multicolumn{2}{|c|}{ Disposal area } \\
\hline & & & Before & \multicolumn{3}{|c|}{ During dredging } & \multirow{2}{*}{$\begin{array}{c}\begin{array}{c}\text { After } \\
\text { dredging }\end{array} \\
\text { 5/Dec }\end{array}$} & \multirow{2}{*}{$\begin{array}{c}\begin{array}{c}\text { Before } \\
\text { dredging }\end{array} \\
25 / \text { March }\end{array}$} & \multirow{2}{*}{$\begin{array}{c}\begin{array}{c}\text { After } \\
\text { dredging }\end{array} \\
\text { 5/Dec }\end{array}$} \\
\hline & & & 25/March & 03/July & 07/Aug & 21/Aug & & & \\
\hline & Transparency (m) & & 2.15 & 2.7 & 1.25 & 3.4 & 2.85 & 15 & 16 \\
\hline Surface & \multirow{3}{*}{$\begin{array}{c}\text { Temperature } \\
\text { water } \\
\left({ }^{\circ} \mathrm{C}\right)\end{array}$} & \multirow{3}{*}{-} & 29.8 & 23.4 & 22.7 & 22.0 & 25.5 & 27.3 & 25.3 \\
\hline $\begin{array}{l}\text { Mid- } \\
\text { water }\end{array}$ & & & - & - & - & - & - & 23.3 & 22.5 \\
\hline deep & & & 25.4 & 22.9 & 21.8 & 21.3 & 23.6 & 20.7 & 21.4 \\
\hline Surface & \multirow{3}{*}{$\mathrm{pH}$} & \multirow{3}{*}{$\begin{array}{c}6.5 \text { to } \\
8.5\end{array}$} & 7.87 & 7.9 & 7.8 & 7.76 & 7.85 & 7.82 & 8.03 \\
\hline $\begin{array}{l}\text { Mid- } \\
\text { water }\end{array}$ & & & - & - & - & - & - & 7.86 & 8.04 \\
\hline Deep & & & 7.69 & 7.8 & 7.9 & 7.9 & 7.59 & 7.84 & 8.09 \\
\hline Surface & \multirow{2}{*}{$\begin{array}{l}\text { Dissolved oxygen } \\
\qquad(\mathrm{mg} / \mathrm{L})\end{array}$} & \multirow{2}{*}{$\begin{array}{l}>5.0 \\
\mathrm{mg} / \mathrm{L}\end{array}$} & 5.66 & 6.44 & 5.07 & 7.28 & 6.18 & 4.96 & 6.48 \\
\hline $\begin{array}{l}\text { Mid- } \\
\text { water }\end{array}$ & & & - & - & - & - & - & 5.57 & 6.18 \\
\hline
\end{tabular}




\begin{tabular}{|c|c|c|c|c|c|c|c|c|c|}
\hline \multirow{3}{*}{ Depth } & \multirow{3}{*}{ Parameters } & \multirow{3}{*}{$\begin{array}{c}\text { CONAM } \\
\text { A 357/05 }\end{array}$} & \multicolumn{5}{|c|}{ Dredging area } & \multicolumn{2}{|c|}{ Disposal area } \\
\hline & & & \multirow{2}{*}{$\begin{array}{c}\begin{array}{c}\text { Before } \\
\text { dredging }\end{array} \\
\text { 25/March }\end{array}$} & \multicolumn{3}{|c|}{ During dredging } & \multirow{2}{*}{$\begin{array}{c}\begin{array}{c}\text { After } \\
\text { dredging }\end{array} \\
\text { 5/Dec }\end{array}$} & \multirow{2}{*}{$\begin{array}{c}\begin{array}{c}\text { Before } \\
\text { dredging }\end{array} \\
25 / \text { March }\end{array}$} & \multirow{2}{*}{$\begin{array}{c}\begin{array}{c}\text { After } \\
\text { dredging }\end{array} \\
5 / \text { Dec }\end{array}$} \\
\hline & & & & 03/July & 07/Aug & 21/Aug & & & \\
\hline Deep & & & 3.57 & 5.52 & 5.34 & 6.63 & 4.58 & 5.62 & 5.19 \\
\hline Surface & & & 29.6 & 33.1 & 32.8 & 32.9 & 33.2 & 33.8 & 34.4 \\
\hline $\begin{array}{l}\text { Mid- } \\
\text { water }\end{array}$ & $\begin{array}{c}\text { Salinity } \\
\text { (\%o) }\end{array}$ & - & - & - & - & - & - & 34.2 & 34.8 \\
\hline Deep & & & 33.4 & 33.6 & 33.4 & 33.2 & 33.6 & 34.5 & 35.1 \\
\hline Surface & & & 0.96 & 2.3 & 3.8 & 0.8 & 2.50 & 0.23 & 0.83 \\
\hline $\begin{array}{l}\text { Mid- } \\
\text { water }\end{array}$ & $\begin{array}{c}\text { Turbidity } \\
\text { (NTU) }\end{array}$ & - & - & - & - & - & - & 1.23 & 0.63 \\
\hline Deep & & & 2.28 & 32.8 & 4.5 & 1.6 & 6.03 & 1.46 & 1.07 \\
\hline Surface & & & 40.0 & 68.5 & 66.0 & 73.5 & 0.5 & 22.4 & 4.5 \\
\hline $\begin{array}{l}\text { Mid- } \\
\text { water }\end{array}$ & $\begin{array}{c}\text { TSS } \\
(\mathrm{mg} / \mathrm{L})\end{array}$ & - & - & - & - & - & - & 34.0 & 2.5 \\
\hline Deep & & & 49.1 & 157 & 70.5 & 73.5 & 9 & 38.9 & 9 \\
\hline
\end{tabular}




\begin{tabular}{|c|c|c|c|c|c|c|c|c|c|}
\hline \multirow{3}{*}{ Depth } & \multirow{3}{*}{ Parameters } & \multirow{3}{*}{$\begin{array}{l}\text { CONAM } \\
\text { A } 357 / 05\end{array}$} & \multicolumn{5}{|c|}{ Dredging area } & \multicolumn{2}{|c|}{ Disposal area } \\
\hline & & & Before & \multicolumn{3}{|c|}{ During dredging } & \multirow{2}{*}{$\begin{array}{c}\begin{array}{c}\text { After } \\
\text { dredging }\end{array} \\
\text { 5/Dec }\end{array}$} & \multirow{2}{*}{$\begin{array}{c}\begin{array}{c}\text { Before } \\
\text { dredging }\end{array} \\
25 / \text { March }\end{array}$} & \multirow{2}{*}{$\begin{array}{c}\begin{array}{c}\text { After } \\
\text { dredging }\end{array} \\
\text { 5/Dec }\end{array}$} \\
\hline & & & 25/March & 03/July & 07/Aug & 21/Aug & & & \\
\hline Surface & \multirow{3}{*}{$\begin{array}{l}\text { Ammonium } \\
\text { (mg/L) }\end{array}$} & \multirow{3}{*}{-} & $<0.02$ & $<0.02$ & $<0.02$ & $<0.02$ & $<0.02$ & $<0.02$ & $<0.02$ \\
\hline $\begin{array}{l}\text { Mid- } \\
\text { water }\end{array}$ & & & - & - & - & - & - & $<0.02$ & $<0.02$ \\
\hline Deep & & & $<0.02$ & 0.06 & $<0.02$ & $<0.02$ & $<0.02$ & $<0.02$ & $<0.02$ \\
\hline Surface & \multirow{3}{*}{$\begin{array}{l}\text { N-Ammoniac } \\
(\mathrm{mg} / \mathrm{L})\end{array}$} & \multirow{3}{*}{$\begin{array}{l}0.70 \\
\mathrm{mg} / \mathrm{L}\end{array}$} & $<0.01$ & $<0.01$ & $<0.01$ & $<0.01$ & $<0.01$ & $<0.01$ & $<0.01$ \\
\hline $\begin{array}{l}\text { Mid- } \\
\text { water }\end{array}$ & & & - & - & - & - & - & $<0.01$ & $<0.01$ \\
\hline Deep & & & $<0.01$ & 0.07 & $<0.01$ & $<0.01$ & $<0.01$ & $<0.01$ & $<0.01$ \\
\hline Surface & \multirow{3}{*}{$\begin{array}{l}\text { Total Phosphorus } \\
\qquad(\mathrm{mg} / \mathrm{L})\end{array}$} & \multirow{3}{*}{$\begin{array}{l}0.093 \\
\mathrm{mg} / \mathrm{L}\end{array}$} & $<0.005$ & 0.03 & $<0.005$ & $<0.005$ & 0.038 & $<0.005$ & $<0.005$ \\
\hline $\begin{array}{l}\text { Mid- } \\
\text { water }\end{array}$ & & & - & - & - & - & - & $<0.005$ & $<0.005$ \\
\hline Deep & & & $<0.005$ & 0.08 & $<0.005$ & $<0.005$ & 0.029 & $<0.005$ & 0.016 \\
\hline
\end{tabular}

Source: Adapted from IVIG (2015) 


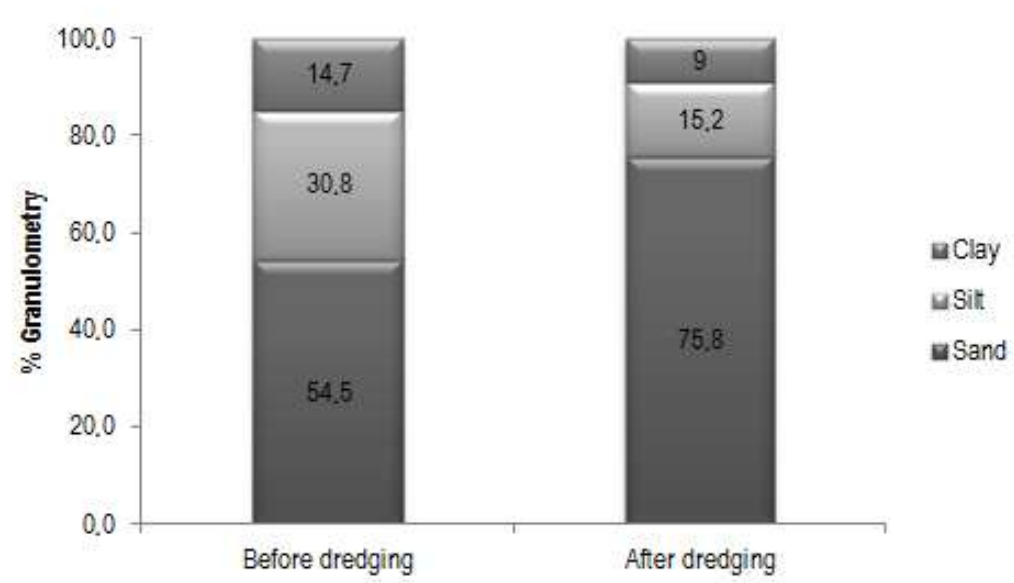

Figure 2: Granulometric characteristics of the sediments at the ocean disposal area before and after the displacement of sediment dredged at the Port of Angra dos Reis. Source: IVIG (2015)

The concentrations of PAHs and organochlorine pesticides and the sum of the PCBs found in the sediments before and after dredging are presented in Table 2. Comparison of the values obtained for these parameters with the CONANA 344/2004 reference values shows that the sediment samples analysed before and after the dredged matter was dumped had concentrations well below Level 1 for saltwater set out in the Resolution, or were at levels so low that they were undetected by the methodology used. Statistical analyses were not performed for concentrations of PAHs, PCBs and organochlorine pesticides due to their low concentrations.

Table 2: Concentrations of polycyclic aromatic hydrocarbons, organochlorine pesticides and polychlorinated biphenyls in the disposal area, before and after disposal of dredging sediments

\begin{tabular}{|c|c|c|c|c|}
\hline \multirow[t]{2}{*}{ Parameters $(\mu \mathrm{g} / \mathrm{Kg})$} & \multicolumn{2}{|c|}{ CONAMA 344/04 } & \multirow{2}{*}{$\begin{array}{l}\text { Before } \\
\text { dredging }\end{array}$} & \multirow{2}{*}{$\begin{array}{c}\text { After } \\
\text { dredging }\end{array}$} \\
\hline & Level 1 & Level 2 & & \\
\hline \multicolumn{5}{|l|}{ PAHs } \\
\hline 2-Methilnaphthalene & 70 & 670 & $<0.51$ & nd \\
\hline Acenaphthene & 16 & 500 & 0.94 & nd \\
\hline Acenaphthylene & 44 & 640 & $<0.37$ & nd \\
\hline Anthracene & 85.3 & 1100 & $<0.65$ & nd \\
\hline Benzo(a)anthracene & 74.8 & 693 & 7.7 & 5 \\
\hline Benzo(a)pyrene & 88.8 & 763 & 9.3 & nd \\
\hline Chrysene & 108 & 846 & 7.15 & nd \\
\hline
\end{tabular}




\begin{tabular}{|c|c|c|c|c|}
\hline \multirow[t]{2}{*}{ Parameters $(\mu \mathrm{g} / \mathrm{Kg})$} & \multicolumn{2}{|c|}{ CONAMA 344/04 } & \multirow{2}{*}{$\begin{array}{l}\text { Before } \\
\text { dredging }\end{array}$} & \multirow{2}{*}{$\begin{array}{c}\text { After } \\
\text { dredging }\end{array}$} \\
\hline & Level 1 & Level 2 & & \\
\hline \multicolumn{5}{|l|}{ PAHs } \\
\hline Dibenz(a.h)anthracene & 6.22 & 135 & 1.78 & nd \\
\hline Phenanthrene & 240 & 1500 & $<0.37$ & 15 \\
\hline Fluoranthene & 600 & 5100 & 14.8 & nd \\
\hline Fluorine & 19 & 540 & 0.94 & nd \\
\hline Naphthalene & 160 & 2100 & $<0.34$ & nd \\
\hline Pyrene & 665 & 2600 & 13.3 & nd \\
\hline Total PAHs & 3000 & & 58 & 25 \\
\hline \multicolumn{5}{|c|}{ Organochloride pesticides } \\
\hline BHC Alpha & 0.32 & 0.99 & $<0.12$ & nd \\
\hline BHC Beta & 0.32 & 0.99 & $<0.12$ & nd \\
\hline BHC Delta & 0.32 & 0.99 & $<0.12$ & nd \\
\hline BHC Gamma & 0.32 & 0.99 & $<0.12$ & nd \\
\hline cis-Chlordane & 2.26 & 4.79 & $<0.37$ & nd \\
\hline DDD (isomers) & 2.26 & 4.79 & $<0.19$ & nd \\
\hline DDE (isomers) & 1.22 & 7.81 & $<0.19$ & nd \\
\hline DDT (isomers) & 2.07 & 374 & $<0.19$ & nd \\
\hline Dieldrin & 0.71 & 4.3 & $<0.23$ & nd \\
\hline Endrin & 2.67 & 62.4 & $<0.23$ & nd \\
\hline trans-Chlordane & 2.26 & 4.79 & $<0.37$ & nd \\
\hline \multicolumn{5}{|l|}{ PCBs } \\
\hline PCBs (sum - Dutch list) & 22.7 & 180 & $<2.59$ & nd \\
\hline
\end{tabular}

Source: Adapted from IVIG (2015) 
The results show that the concentrations of the transition metals and semi-metals (arsenic) analysed in the sediments were consistently lower than the reference values set out in CONAMA Resolution 344/2004 (Tab. 3). Higher concentrations of As, $\mathrm{Cd}$ and Pb were found in the sediments after the end of the disposal of the dredged matter. Post-dredging, a concentration of arsenic slightly higher than Level 1 of the Resolution $(10 \mathrm{mg} / \mathrm{kg})$ was detected at point BF-A2.

In general, the distribution of metals in the sediments of the disposal area was considerably homogenous, with similar concentrations between the sampling sites. A heterogeneous distribution of copper and chromium was, however, observed in the sediments after dredging. Higher concentrations of copper were detected at station BF-A1 (26.3\%) than at station BF-A2 (7.1\%), whereas station BF-A2 contained a higher concentration of chromium (51\%) than did BF-A1 (25\%).

Table 3: Concentration of metals and semi-metals in the sediments of the ocean disposal area before and after the dumping of the sediments dredged from the Port of Angra dos Reis

\begin{tabular}{ccccc}
\hline $\begin{array}{c}\text { Metals and } \\
\begin{array}{c}\text { Semi-metals } \\
\text { (mg/Kg) }\end{array}\end{array}$ & CONAMA 344/04 & Before dredging & After dredging \\
\cline { 1 - 4 } & Level 1 & Level 2 & & \\
\hline Arsenic & $\mathbf{8 . 2}$ & $\mathbf{7 0}$ & $<0.6$ & 5 \\
\hline Cadmium & $\mathbf{1 . 2}$ & $\mathbf{9 . 6}$ & $<0.056$ & 0.4 \\
\hline Lead & $\mathbf{4 6 . 7}$ & $\mathbf{2 1 8}$ & 3.35 & 12.8 \\
\hline Copper & $\mathbf{3 4}$ & $\mathbf{2 7 0}$ & 14.5 & 36.7 \\
\hline Chromium & $\mathbf{8 1}$ & $\mathbf{3 7 0}$ & 8.65 & nd \\
\hline Mercury & $\mathbf{0 . 1 5}$ & $\mathbf{0 . 7 1}$ & $<0.028$ & 3.6 \\
\hline Nickel & $\mathbf{2 0 . 9}$ & $\mathbf{5 1 . 6}$ & 3 & 43.9 \\
\hline Zinc & $\mathbf{1 5 0}$ & $\mathbf{4 1 0}$ & 25 & \\
\hline
\end{tabular}

Source: Adapted from IVIG (2015)

In terms of the physicochemical indicators (TOC, nitrogen and phosphorous), the readings in the final disposal area showed values significantly below the alert levels specified in CONAMA Resolution 344/2004 (Tab. 4). A homogenous distribution of nutrients and organic matter was observed in the sediments given that similar concentrations were registered at the sampling stations. After the dredging, a decrease in the concentration of total $\mathrm{N}$ and TOC was observed in the sediments. 
Table 4: Concentration of total organic carbon and total nitrogen and phosphorus in sediments from the disposal area before and after the dumping of the sediments dredged from the Port of Angra dos Reis.

\begin{tabular}{lcccc}
\hline \multicolumn{1}{c}{ Nutrients and TOC } & CONAMA 344/04 & $\begin{array}{c}\text { Before } \\
\text { dredging }\end{array}$ & $\begin{array}{c}\text { After } \\
\text { dredging }\end{array}$ \\
\hline Total Organic Carbon (\%) & 10 & 0.59 & 0.35 \\
\hline Total Phosphorus (mg/Kg) & 2000 & 192 & 215.5 \\
\hline Total Kjeldahl Nitrogen (mg/Kg) & 4800 & 765 & 264.5 \\
\hline
\end{tabular}

Source: Adapted from IVIG (2015)

\section{DISCUSSION}

\subsection{Dredged Area}

The results obtained from the in situ readings during three phases (before, during and after dredging) for the parameters of temperature, salinity and $\mathrm{pH}$ demonstrated comportment that correlated exclusively with oceanographic and seasonal conditions. No interference by the dredging was observed.

The highest temperatures in internal bay waters were recorded for samples collected closest to the summer (March to December 2010), and lower temperatures were expected during the dredging period (July and August 2010) because the sampling undertaken during the dredging work took place in the winter. According to Magliocca et al. (1979), the water in the internal bay area heats up considerably during the summer, which alters the temperature of the whole of the neighbouring coastal region.

No variation was observed in salinity with regard to depth in the dredging area, despite the fact that the dredging area was located in an estuary. According to Abreu et al. (2009), the deeper levels of estuary environments exhibit higher salinity levels, which characterises the presence of a saline wedge. According to the report of the National Institute for Research into Waterways (INPH, 2009), however, the Bay of Iha Grande, which is deep and features a wide opening to the ocean, is subject to a greater degree of influence by continental shelf water, which is colder and saltier. INPH (2009) also indicates that the waters of the Bay of Ilha Grande are more saline and slightly warmer than those of Sepetiba Bay - an adjacent area interlinked to the Ilha Grande Bay. The stability of the $\mathrm{pH}$ and its alkaline values is also explained by the major influence of continental shelf waters in the area under study. Saline water has a buffering effect and exhibits alkalinity values higher than those of freshwater (Nybakken \& Bertness, 2004).

Dissolved oxygen was not considered a good indicator for the area in question because lower concentrations were detected in the near-bottom pre-dredging samples. The observed conditions 
are related to the precariousness or absence of sanitation infrastructure in the region, which results in a major presence of organic matter in the environment and leads to strong consumption of D.O. (CDRJ, 2008). It can also be inferred that a sample taken from slack water of an ebb tide reflected the complete mixture of continental and oceanic water, which excludes any possibility of positive or negative influence from the activity of dredging.

The characterisation of the area of dredging, prior to the commencement of work, indicated very low concentrations of nutrients but higher parameters of turbidity and TSS than in the disposal area because of the dredging area's proximity to the coast. According to the CDRJ (2008), the nonconsolidated sedimentary flows that shift due to meteorological and hydrodynamic factors, combined with the type of use and occupation of the soil, continuously transfer a significant quantity of suspended matter into Ilha Grande Bay. The concentration of TSS and the turbidity readings of the water column may therefore vary considerably, irrespective of dredging processes.

A small increase in turbidity and in the concentration of total suspended solids and phosphorous was observed in the water column during the dredging period. According to Torres (2000) and Abreu et al. (2009), these alterations are expected during these activities because of the revolving of sediments deposited in the region. In the July 2010 samples, peaks in the turbidity ( 32.8 NTU), TSS (157 mg/L) and phosphorous $(0.08 \mathrm{mg} / \mathrm{L})$ were noted in the deeper layer. However, these increased readings were recorded at times when the dredger was operating near the monitoring sites, and the readings remained within the limits established by CONAMA Resolution 357/2005 for class 2 saline water.

At the end of the dredging, a decrease in the concentration of TSS in the water column was noted, along with an increase in the local turbidity, compared to the pre-dredging campaign. These facts might be related to the presence of finely divided organic and inorganic matter and microscopic organisms that are not caught by the filters used for TSS analysis. According to Nybakken \& Bertness (2004), among marine plankton, a group classified as picoplankton comprise minute organisms $0.2-2 \mu \mathrm{m}$ in size and consist primarily of bacteria and cyanobacteria. Thus, these organisms would not be retained on the filter used for the TSS determination $(2 \mu \mathrm{m})$, but the high presence of these organisms would increase local turbidity.

No alteration was observed in the concentrations of ammonia and $\mathrm{N}$-ammoniac throughout the monitored period, during which they remained at low concentration levels or were not detected.

The results obtained from the monitoring indicated, in general terms, a low level of interference by the dredging in the water in the area of influence of the dredging. Interference, when it did occur, was local and short-term. Only the turbidity, TSS and phosphorous parameters indicated that the dredging activity led to alterations in the water column with re-suspension and shifting of matter from the seabed, as observed in the reading taken at the near-bottom in July 2010. Although the results observed for phosphorous registered values below the threshold limit, the dredging probably shifted this nutrient to the water column.

The water quality in estuarine areas is subject to multiple anthropogenic or naturally occurring stress factors, such as physical, chemical and microbiological agents that originate from 
agricultural and urban runoff, municipal sewage, industrial wastewater and navigation traffic (Urban et al., 2010). In terms of their physicochemical characteristics, estuaries are not steady-state systems, which makes the special and temporal assessment of their quality an interesting challenge (Förstner, 2004). Therefore, the additional complexity in such ecosystems derived from dredging operations is difficult to explain without previous studies on this specific area.

The absence of water-quality studies specific to the Port of Angra dos Reis limits the interpretation of the results. Comparisons of results obtained in the Port of Angra with other regions within the Bay of Ilha Grande are not ideal because the port area is subject to unique stresses, which can lead to different characteristics from other regions within the same bay.

\subsection{Disposal área}

\subsubsection{Water}

In the disposal area, before and after dredging, both the physical parameters measured in situ and the chemical parameters demonstrated that the water variables had not suffered disturbance due to the disposal of dredged matter. The dominant force was, rather, intense oceanographic movement. No variation that might be attributed to the dredging was observed.

The results of the analyses of water variables prior to dredging demonstrated that the ocean disposal area was a location with very low concentrations of nutrients (below detectable levels) and with typical marine standards of physicochemical parameters (D.O., pH, salinity, temperature, transparency, turbidity and TSS). After the termination of dredging, the area continued to have the same characteristics, with a reduction in the concentration of TSS being the only observed change. These results might be related to the natural variations in large volumes of water mass subject to coastal currents that are typical of the marine environment for this region of the continental shelf (Mahiques \& Fujikawa, 1995).

\subsubsection{Sediment}

The characterisation of the disposal area indicated that, before the dredged matter from the Port of Angra dos Reis was dumped, the region was composed predominantly of sandy-silty sediment. However, after the disposal of the dredged material, the area became predominantly sandy, with a noticeable reduction in the concentration of fine sediment, particularly silt.

The material dredged from the port was predominantly silty-clay (CDRJ, 2008); nevertheless, we found no dredging sludge originating from the disposal area. The alteration of the granulometric characteristics of the disposal area may be the result of oceanographic conditions such as the direction and speed of bottom currents (Gomes et al., 2009). We conclude that the environment in question has dispersive characteristics, probably conditioned by the variability of coastal currents and the ability of these currents to transport sediments by traction across the region receiving sediment from streams adjacent to the seabed. This region is conditioned mainly by tides and highmagnitude weather events such as storms (Noernberg et al., 2007). According to Mahiques (1998) and Castro Filho et al. (1987), the region bounded in the area of ocean disposal is subject to seasonal dynamic phenomena related to the penetration of the South Atlantic Central Water (SACW) at bottom, which moves toward the shallower portions of the platform. Mahiques (1998) has 
postulated that the advance of SACW leads to the displacement of coastal water mass in the surface direction of the outer continental shelf. This displacement would lead to the deposition of organic matter and the finer sediment fractions associated with it in the deeper portions of the platform (Mahiques \& Fujikawa, 1995).

Several organic contaminants exhibit low solubility in water; they are therefore associated with suspended matter and are transported to the bottom via the displacement of sediment (Davis et al., 1990). Although the contaminant content in sediments is site- and time-dependent and metals such as copper, lead, mercury and zinc and organic compounds such as pesticides, PCBs and PAHs are, in general, the major contaminant constituents (Long, 2002). The pollutant concentrations also depend on the characteristics of the sediment; sediments composed of clay and silt have a larger absorption capacity (Freret-Meurer et al., 2010).

In terms of the chemical characterisation of the sediments in the disposal area, it was noted, prior to the dumping of the sediment, that all the elements analysed presented concentrations far lower than level 1 of CONAMA Resolution 344/2004 (Brasil, 2004). The evaluation of the sediments after the end of the dumping of the sediments indicated that the sediments continued to have concentrations of PAHs, PCBs, pesticides, COT, total N and $\mathrm{P}$ that were significantly lower than the concentrations specified as level 1 of CONAMA 344/2004 or were at undetectable levels. The results in terms of the physico-chemical indicators (TOC, nitrogen and phosphorous) were, as expected, typical of an oceanic region.

However, a significant increase was observed in the concentrations of some of the analysed metals after the end of the dumping ( $\mathrm{As}, \mathrm{Cd}$ and $\mathrm{Pb}$ ). These higher concentrations might be related to the greater concentration of heavy metals in the dredged sediments. The analysis of the dredged sediments indicated the presence of some elements at concentrations between levels 1 and 2 of CONAMA 344/2004 (CDRJ, 2008). Possible sources of metals to the Bay of Ilha Grande are the weathering of rocks, atmospheric deposition and, primarily, the release of industrial and domestic effluents (Teixeira, 2009). The metal contamination in sediments in Ilha Grande Bay has been observed in several studies, such as those of Gomes et al. (2009), Teixeira (2009) and Freret-Meurer et al. (2010).

The fact that there was no increase in the levels of heavy metals in the disposal area sediment above level 1 of the Resolution should be emphasised. However, we still cannot affirm that there is no adverse effect on the biota at these new metal concentrations because no ecotoxicological tests have been performed. Although concentrations were below level 1 , the effects of such enrichment require attention, especially with regard to biological and ecological effects. In addition, concentrations of arsenic greater than Level 1 were recorded at one monitoring site in the disposal area (BF-A2). The effects of the arsenic have to be studied further because adverse effects are probably induced when arsenic levels violate the level 1 threshold.

\section{CONCLUSION}

This study reinforces the need, as stated by Koehler \& Asmus (2009), for systematic monitoring of the water quality in port regions to evaluate the variability that occurs in environmental parameters outside periods of dredging activity. Such monitoring would provide highly relevant information that would facilitate the identification of the precise effects of dredging 
by allowing the use of comparative data from the non-dredging periods. This data would therefore provide an additional management tool to enable the diagnosis, detection and adoption of control measures in the event of an impact related to dredging being detected.

In addition to the lack of environmental information prior to dredging, another factor that limits the detection of possible environmental impacts from the dredging is the small number of sampling sites determined by the governing environmental agency (INEA) to establish the sampling design of environmental monitoring. The small sample size does not allow statistical analysis to detect variations. Thus, we recommend a more detailed review in the licensing system required by the environmental agency.

The analysis of the water in the dredging area indicates that there was no interference of dredging in most parameters. The only changes observed were recorded in the dredging area with increased turbidity, TSS and phosphorus during the dredging. For the disposal area, no change in water variables that could be attributed to dredging were observed.

Bearing in mind the results for the sediments are presented and evaluated in light of CONAMA Resolution 344/2004, we conclude that the samples from the disposal area were composed primarily of sand and did not contain contamination above level 1 for the parameters investigated, even after the disposal of the dredged material. However, we observed a significant increase in the concentrations of some metals in the disposal area after dredging. Although concentrations were below level 1 , we cannot affirm that there is no adverse effect on the biota. To affirm that there will be no adverse effects on the biota, biological analyses, such as ecotoxicological tests, are required.

\section{REFERÊNCIAS}

ABNT (Associação Brasileira de Normas Técnicas). 1995. NBR 6502. Rochas e solos. 18 p.

ABREU, J. G. N.;. RÖRIG, L.R.;.FILHO J.P.; D’AQUINO C.A.; RESGALLA JUNIOR, C.; BELLOTTO, V.R.; MENEZES, J.T.; BURATO, D.S.; VIVAN, J.M.; NUNES, R.D.; POLEZA, F.; COSTODIO. P.F.S. (2009) Monitoramento Ambiental do Rio Itajaí-Açu na área de influência do Porto de Itajaí - SC. In: BOLDRINI, E. B.; PAULA E. V. de (Org). Gestão Ambiental Portuária: Subsídios para o licenciamento das dragagens. 1 ed. Antonina: Ademadan, p. 257-271.

APHA (American Public Health Association). 2005. Standard methods for the examination of water and wasterwater. 210 Ed. American Water Works Association (AWWA), Water Environment Federation (WEF). Washington, DC. 1368 p.

Brasil, 2004. Resolução Conama no 344, de 25 de março de 2004. Estabelece as diretrizes gerais e os procedimentos mínimos para a avaliação do material a ser dragado em águas jurisdicionais brasileiras, e dá outras providências. Disponible in http://www.mma.gov.br.

Brasil, 2005. Resolução Conama no 357, de 17 de março de 2005. Dispõe sobre classificação dos corpos de água e diretrizes ambientais para o seu enquadramento, bem como estabelece as condições e padrões de lançamento de efluentes, e dá outras providências. Diário Oficial da República Federativa do Brasil, Brasília, DF, v. 142, no 53, Seção 1, pp. 58-63. 
Castro Filho, B. M.; Miranda L. B.; Miyao, S.Y. Condições hidrográficas na plataforma continental ao largo de Ubatuba: variações sazonais e em média escala. Bol. Inst. Oceanogr., S. Paulo, São Paulo, v 35, n 2, p.135-151, 1987

CDRJ (Companhia Docas do Rio de Janeiro). 2008. Dragagem do canal de acesso, bacia de evolução e berços de atracação do Porto de Angra dos Reis. Relatório de Interpretação dos Resultados das análises dos sedimentos da Companhia Docas do Rio de Janeiro, Rio de Janeiro, 24 pp.

Davis, J.D., MacKnight, S.; Staff, I. M. O. Environmental Considerations for port and harbor developments. (1990). World Bank Technical Paper $n^{\circ} 126$, Washington, 83 pp.

Förstner, U. Sediments dynamics and pollutant mobility in rivers: an interdisciplinary approach. (2004). Lakes Res: Res Manag., CIDADE v 9, p. 25-40.

Freret-Meurer, N.V.; Andreata, J.V.; Meurer, B.C.; Manzano, F.V.; Baptista, M.G.S.; Teixeira D.E.; Longo. M.M. (2010). Spatial distribution of metals in sediments of the Ribeira Bay, Angra dos Reis, Rio de Janeiro, Brazil. Mar. Pol. Bul., cidade v 60, p. 627-629.

Gibertoni, C.A.C. 1998. A lei de modernização dos portos. Disponible in http://www.geocities.com/ ambitojuridico/da0016.html. Reviewed: 20 april 2011.

Góes, F. H. A. Gerenciamento Ambiental de Dragagem e Disposição do Material Dragado, (2002). Rio de Janeiro: Planágua Semads/GTZ, Cooperação Técnica Brasil/ Alemanha, 35 pp.

Gomes, F.C.; Godoy, J. M.; Godoy, M.L.D.P.; Carvalho, Z. L.; Lopes, R. T.; Sanchez-Cabeza, J. A.; Lacerda L.D.; Wasserman J.C. (2009). Metal concentrations, fluxes, inventories and chronologies in sediments from Sepetiba and Ribeira Bays: A comparative study. Mar. Pol. Bul., v 59, p. 123-133.

Ikeda, Y.; Stevenson, M.R. (1982). Seasonal characteristics of hidrography, turbulence and dispersion near llha Grande (Rio de Janeiro-Brazil), based on R/V Prof. W. Besnard. Bol. Inst. Oceanogr. São Paulo, v 31, n 1, p. 11-32.

IMO (International Maritime Organization). 2005. Sampling of dredged material: guidelines for the sampling and analysis of dredged material intended for disposal at sea. International Maritime Organization, London, 21pp.

INPH (Instituto Nacional de Pesquisas Hidroviárias). 2009. Projeto básico de Engenharia de dragagem do canal de acesso ao porto de Angra dos Reis - RJ. Relatório técnico do INPH da Secretaria Especial de Portos da Presidência da República, RJ, 28 pp.

IVIG - Instituto Virtual Internacional de Mudanças Globais, Universidade Federal do Rio de Janeiro (UFRJ), (2015). Gerenciamento ambiental das obras de dragagem do Porto de Angra dos Reis, Relatório Técnico, Rio de Janeiro.

Kennish, M.J. 1994. Practical Handbook of Marine Science. John Wiley \& Sons. New York. 562 pp.

Koehler, P.H.W. \& M.L. Asmus. 2009. Sistemas de Informações de Monitoramento como instrumento para Gestão Ambiental Portuária. In: E.B. Boldrini \& E.V. de Paula (eds). Gestão 
Ambiental Portuária: Subsídios para licenciamento de dragagens. Ademadan Antonina, Curitiba, pp. 129-143.

Long, E.R. Degraded sediment quality in US estuaries: a review of a magnitude and ecological implications. Ecol. Appl., cidade v 10, p. 338-349, 2002.

Magliocca, A.; Miranda L.B.; Signorini. S.R. (1979). Physical and chemical aspects of transiente stages of the upwelling at southwest of Cabo Frio (Lat. $23^{\circ} \mathrm{S}-$ Long. $42^{\circ} \mathrm{W}$ ). Bol. Inst. Oceanogr., São Paulo, v 28, n 2, p. 37-46.

Mahiques, M.M. (1998). Características da Matéria Orgânica Sedimentar da Plataforma Continental Interna e Média entre a Baia de Guanabara (RJ) e São Francisco do Sul (SC). Tese de Doutorado. Instituto Oceanográfico. Universidade de São Paulo. 86 p.

Mahiques, M. M.; Fujikawa, L. H. (1995). Calcium carbonate, organic carbon and nitrogen contents, and coarse fraction constituents in the superficial sediments of São Paulo State inner and medium continental shelf. In: LOICZ (Land-Ocean Interactions in the Coastal Zone) Scientific Meeting. Program and Abstracts. São Paulo: ABEQUA, p. 20-22.

Nybakken, J.W.; Bertness. M.D (2004). Marine Biology: An Ecological Approach. San Francisco: Benjamin Cummings, 2004.

Noernberg, M., E. Marone \& R. Angulo. Coastal Currents and Sediment Transport in Paranagua Estuary Complex Navigation Channel. (2007). Boletim Paranaense de Geociências, Curitiba, v 60-61, p. 45-54.

Teixeira, C.L. (2009). Caracterização do sedimento superficial de enseadas da Baía de Ilha Grande RJ, com ênfase na distribuição espacial de metais. Dissertação de Mestrado, Universidade Federal Fluminense, $103 \mathrm{p}$.

Torres, R.J. (2000). Uma análise preliminar dos processos de dragagem do Porto do Rio Grande, RS. Dissertação de mestrado, Fundação Universidade Federal do Rio Grande. 179 p.

Torres, R.J.; Abessa, D.M.S.; Santos, F.C.; Maranho, L.A.; Davanso, M.B.; Nascimento, M.R.L.; Mozeto, A.A. (2009). Effects of dredging operations on sediment quality: contaminant mobilization in dredged sediments from the Porto of Santos, SP, Brazil. J. Soils Sediments, v 9, p. $420-432$.

Urban, S.R., A.X.R. Corrêa, C.A.F. Schettini, P.R. Schwingel, R.M. Sperb \& C.M. Radetski. 2010. Physicochemical and ecotoxicological evaluation of estuarine water quality during a dredging operation. J. Soils Sediments, 10: 65-76.

USACE (United State Army Corps of Engineers). 1998. Use of sediment quality guidelines (SQGs) in dredged material management. Dredging Research Technical Note EEDP-04-29, Washington, $14 p$.

USEPA (United State Environmental Protection Agency). 1996. Acid digestion of sediments, sludges and soils. Method 3050B (SW-846). Revision 2. 12pp. 
USEPA (United State Environmental Protection Agency). 1998. Semivolatile Organic Compounds by Gas Chromatography/Mass Spectrometry (GC-MS). Method 8270D (SW-846). Revision 4. 62 pp.

USEPA (United State Environmental Protection Agency). 2007a. Ultrasonic extraction. Method 3550C (SW-846). Revision 3. 17pp.

USEPA (United State Environmental Protection Agency). 2007b. Inductively Coupled Plasma - Atomic Emission Spectroscopy. Method 6010C (SW-846). Revision 3. 34pp.

Wentworth, C. K. 1922. A scale of grade and class terms for clastic sediments. J. Geology, 30(5): 377-392. 